\title{
Results of Testing and Research Design for Mitigation of Site 41MS32, A Burned Rock Midden Site in Mason County, Texas
}

Cultural Resources Staff

Follow this and additional works at: https://scholarworks.sfasu.edu/ita

Part of the American Material Culture Commons, Archaeological Anthropology Commons, Environmental Studies Commons, Other American Studies Commons, Other Arts and Humanities Commons, Other History of Art, Architecture, and Archaeology Commons, and the United States History Commons

Tell us how this article helped you.

This Article is brought to you for free and open access by the Center for Regional Heritage Research at SFA ScholarWorks. It has been accepted for inclusion in Index of Texas Archaeology: Open Access Gray Literature from the Lone Star State by an authorized editor of SFA ScholarWorks. For more information, please contact cdsscholarworks@sfasu.edu. 


\section{Results of Testing and Research Design for Mitigation of Site 41MS32, A Burned Rock Midden Site in Mason County, Texas}

\section{Licensing Statement}

This is a work produced for the Texas Department of Transportation (TxDOT) by the report producer. TxDOT and the report producer jointly own all rights, title, and interest in and to all intellectual property developed under TXDOT's contract with the report producer. The report may be cited and brief passages from this publication may be reproduced without permission provided that credit is given to both TXDOT and the report producer. Permission to reprint an entire chapter, section, figures or tables must be obtained in advance from either the Supervisor of the Archeological Studies Branch, Environmental Affairs Division, Texas Department of Transportation, 125 East 11th Street, Austin, Texas, 78701 or from the report producer. 


\title{
RESULTS OF TESTING AND RESEARCH DESIGN FOR MITIGATION OF SITE 41MS32, A BURNED ROCK MIDDEN SITE IN MASON COUNTY, TEXAS
}

\author{
BY \\ Cultural Resources Staff
}


TABLE OF CONTENTS

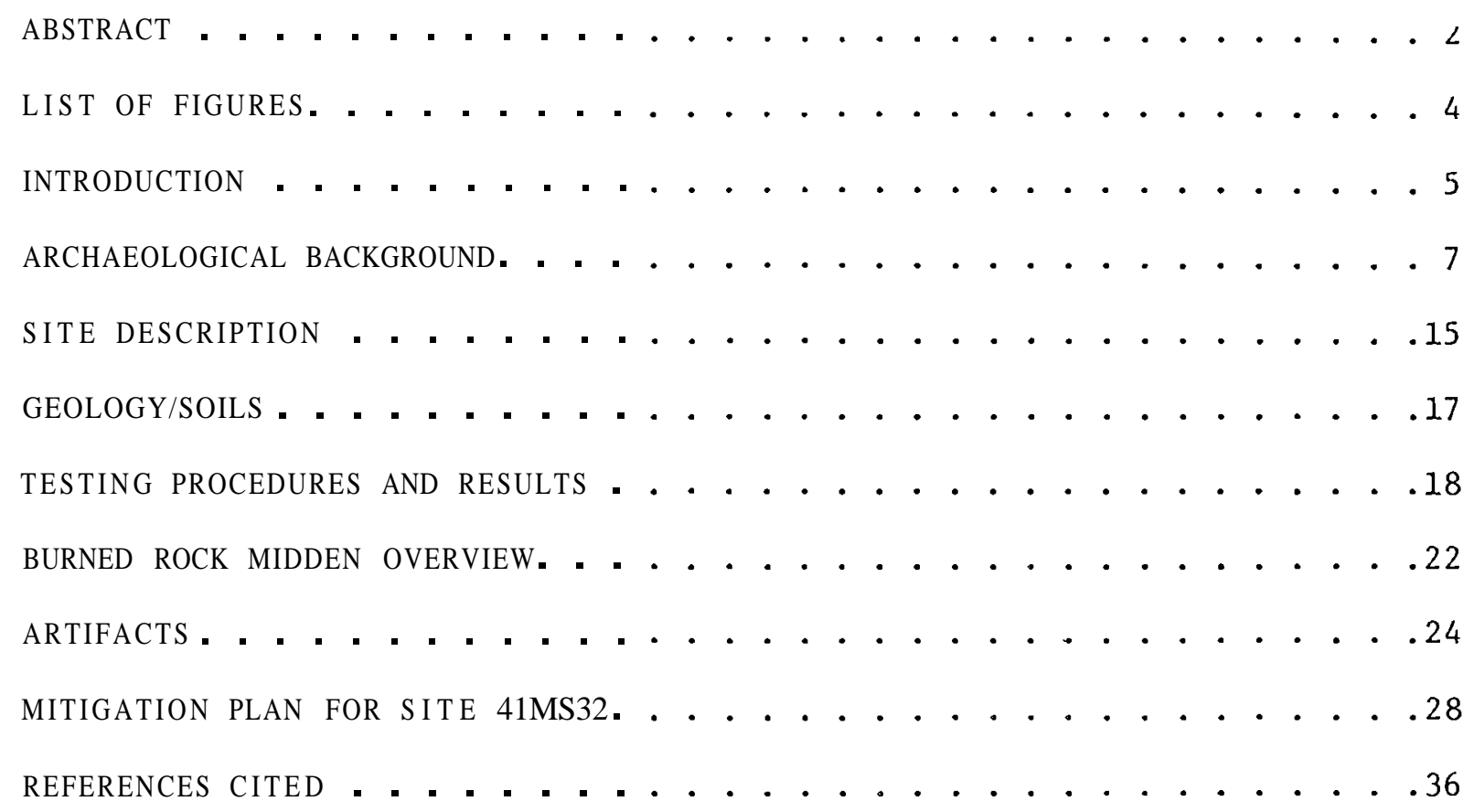




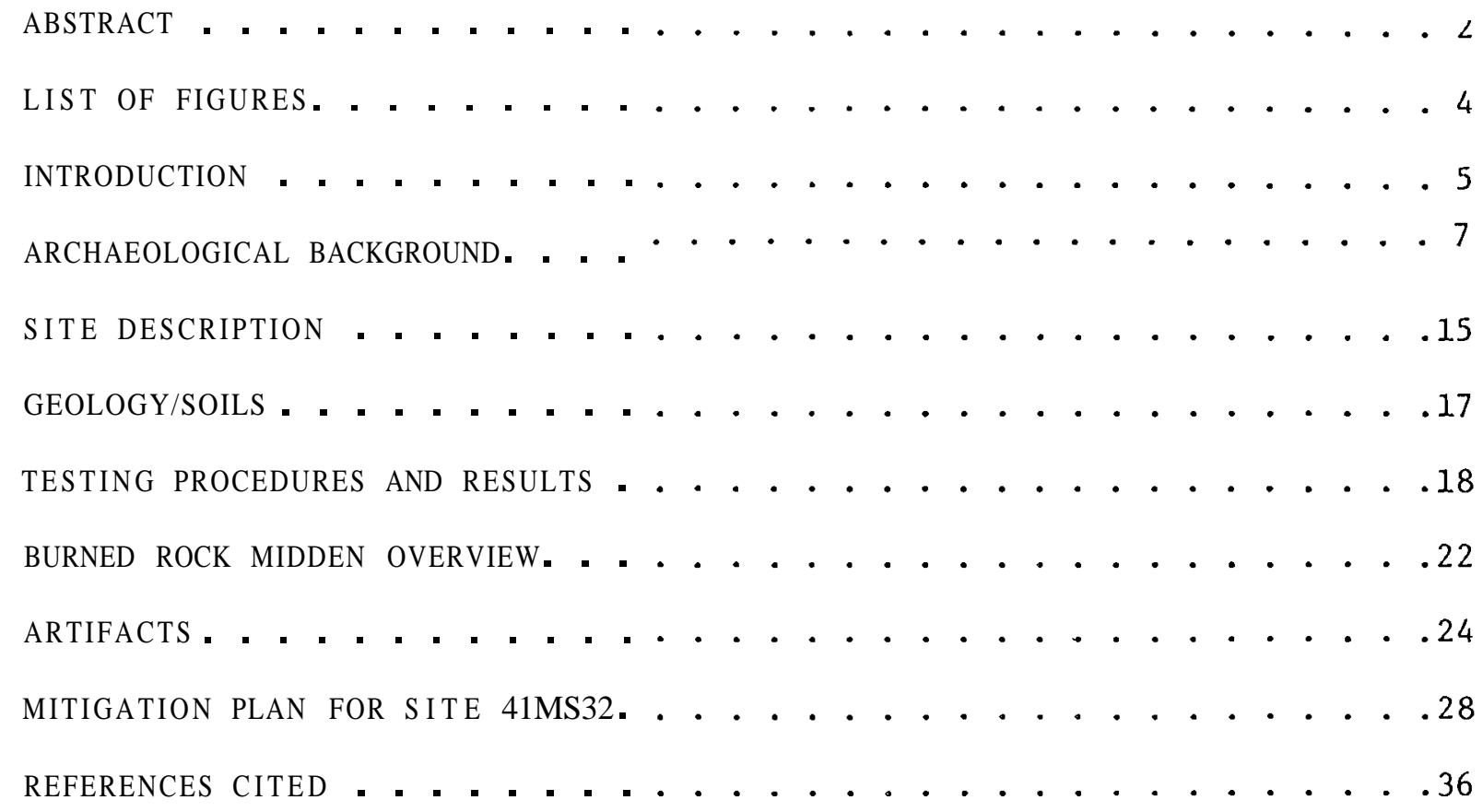




\section{LIST OF FIGURES}

FIGURE 1. Location of Site 41MS32 in Mason County. Texas . . . . . . . 6

FIGURE 2. Plan view of site showing test units and Gradall trenches. . . .19

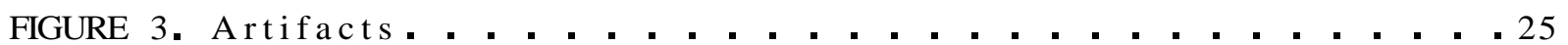




\section{INTRODUCTION}

Site 41MS32 was reported in October 1987 during the preliminary engineering stage of a bridge replacement project at Honey Creek on FM 1871 in Mason County. The project calls for a new bridge on new location downstream from the old bridge. The right-of-way for the new bridge and approaches will vary from $85 \mathrm{ft}$. to $100 \mathrm{ft}$. in width.

Site 41MS32 occurs partly in the new right-of-way for realigned FM 1871, 7.3 miles southwest of the FM 1871 and US 87 intersection in the city of Mason. The site is located on the north bank of Honey Creek, a major tributary of the Llano River, about 2 miles from the river in southwestern Mason County (Fig. 1). Cultural material is known to exist over several acres, the most visible manifestation being a single burned rock midden located at the western margin of the site.

The site was tested during the period November 3-12, 1987, by a crew of six employees of the Texas State Department of Highways and Public Transportation (SDHPT). The project was directed by Glenn T. Goode, a member of the SDHPT professional cultural resources staff.

A brief summary of that testing is presented herein along with a research design for final mitigation of the site. 
This Page Redacted Per THC Policy 
ARCHAEOLOGICAL BACKGROUND

Mason County is situated in the central portion of what has been defined as the Central Texas Archaeological Region (Weir 1976; Prewitt 1981a; Brown et al. 1982). The four basic culture periods which have been defined for the state and nation as a whole are included in the Central Texas Archaeological Region as well. These periods are the Paleo-Indian Period, the Archaic Period, the Late Prehistoric Period, and the Historic Period.

The earliest cultural period, the Paleo-Indian, began sometime prior to 10,000 B.C. and represents a period of Late Pleistocene large-game hunting by members of small, highly mobile cultural groups. The Paleo-Indian Period has been associated with the last glacial period of the Wisconsin Ice Age. The period is recognized archaeologically by fluted and lanceolate projectile points such as Clovis, Folsom, and Plainview, which are sometimes associated with extinct forms of Pleistocene fauna. The period was fairly homogeneous throughout North America, although regional expressions are known.

No Paleo-Indian sites are known from Mason County, although several have been excavated in the Central Texas Archaeological Region. Some of the more significant Paleo-Indian sites are the Pavo Real Site in Bexar County (Henderson 1983), the Wilson-Leonard Site in Williamson County (Young 1985a), and the Levi Rockshelter Site in Travis County (Alexander 1963).

The Paleo-Indian Period ended about 6500 B.C. upon the extinction of the Late Pleistocene megafauna and the decline of the glaciation. The concomitant need to devise new subsistence strategies in order to deal with the changing environment heralded a new culture period known as the Archaic. The Archaic Period saw 
a change from the specialized large-game hunters of the Pleistocene to a generalized hunting and gathering pattern with many diverse localized and regional forms. The change was gradual and a transitional Paleo-Indian/Early Archaic Period is now recognized in some archaeological contexts. An early projectile point type which is considered to be Late Paleo-Indian/Early Archaic is the Angostura. This type has been recovered underlying Early Archaic forms at the Heard Site (Hendersonn.d.) and overlying Plainview points at the Wilson-Leonard Site (Young 1985a). At the Wilson-Leonard Site numerous Angostura points were recovered in association with Gower points, another diagnostic transitional Early Archaic type. Associated with these types and considered to be typical of the period are large, basin-shaped hearths, sometimes 2 meters in diameter and $30 \mathrm{~cm}$ thick (Young 1985a).

The Archaic Period itself is widely known throughout Central Texas and makes up the bulk of the archaeological literature. The period has been divided into five phases by Weir (1976) and eleven phases by Prewitt (1981a), based on temporal and geographical aspects of projectilepoint morphologies and their associated materials.

The earliest Archaic Phase was defined by Weir (1976) as the San Geronimo Phase and is thought to encompass the period from about 6500 B.C. to about 3000 B.C. The phase is characterized by Bell, Uvalde, Martindale, and "Early Barbed" projectile point types. Burned rock middens appeared late in the San Geronimo Phase (Weir 1976). Prewitt (1981a) further divided the phase into four phases based generally on single projectile point types associated with discrete radiocarbon dates rather than on Weir's (1976) co-occurring types. Prewitt's (1981a) phases are, from earliest to latest, Circleville, San Geronimo, Jarrell, and Oakalla. 
Following Weir's San Geronimo Phase was Weir's (1976) and Prewitt's (1981a) Clear Fork Phase, dating from about 3000 B.C. to 2000 B.C. This phase is characterized by Tortugas, Travis, Nolan, and Bulverde projectile point types. Two types of burned rock middens can be identified with the Clear Fork Phase: the typical oval mound (Weir's Type 1) and the less common circular aggregation of burned rocks containing a central pit (Weir's Type 2) (Weir 1976).

Weir's (1976) Round Rock Phase followed the Clear Fork Phase and dated from about 2000 B.C. to about 500 B.C. Characteristic of the Round Rock Phase are $\underline{\text { Pedernales, Langtry }}$, and Val Verde projectile points. Type 1 burned rock middens are also associated with the Round Rock Phase. Prewitt (1981a) divided the Round Rock Phase into the earlier Marshall Ford and the later Round Rock phases.

Following the Round Rock Phase was Weir's (1976) San Marcos Phase, dating from around 500 B.C. to around A.D. 150. The phase is characterized by Lange, Castroville, Montell, Marshall, and Marcos projectile point types. Three types of burned rock middens are associated with the San Marcos Phase: the common oval mound (Type 1), the circular aggregation containing a central pit (Type 2), and a pit excavated into the original ground surface surrounded by a crescent of rocks (Type 3) (Weir 1976). Prewitt (1981a) divided the San Marcos Phase into an earlier San Marcos Phase and a later Uvalde Phase.

Following the San Marcos Phase was Weir's (1976) Twin Sisters Phase, dating from around A.D. 150 to about A.D. 1250 (Weir 1976). Since Weir's time, the terminal date has been much in question and has been moved back to around A.D. 500-700 (see for example, Shafer 1971 and Prewitt 1981a). The Twin Sisters Phase is characterized by Ensor, Frio, and Darl projectile point types, and Type 2 and 
Type 3 burned rock middens (Weir 1976). Prewitt (1981a) has divided Weir's Twin Sisters Phase into an earlier Twin Sisters Phase and a later Driftwood Phase.

Numerous Archaic sites are known throughout the Central Texas Archaeological Region. Many are burned rock midden sites and virtually all are multicomponent sites; that is, several of Weir's and Prewitt's phases are usually present at single sites. A brief sketch of a few of the excavated sites is given below.

In eastern Kimble County, just west of Site 41MS32, the SDHPT excavated a series of six Archaic sites along FM 479 near the James River (Young 1986). At Site 41MS61 materials from a 11 of Weir's (1976) phases were recovered, but the greatest quantity represented the Round Rock (Pedernales and Bulverde dart points), San Marcos (Montell, Marshall, Castroville, Marcos, and Williams types), and Twin Sisters (Frio, Ensor, and Edgewood) phases. Two burned rock middens seemed to be associated with the San Marcos and Twin Sisters materials, while no evidence was found to link the Round Rock Phase to either midden.

A second site, 41KM62, produced materials from every Archaic phase except San Geronimo, although the majority of the materials (Pedernales points) represented the Round Rock Phase. Burned rock middens and a quantity of ground stone artifacts were also present at the site (Young 1986).

A small campsite (41KE93) on the south bank of the Guadalupe River in Kendall County was also excavated by the SDHPT (Young 1987). This-site produced artifacts from the Round Rock ( $\underline{\text { Pedernales }}$ points), san Marcos (Castroville and

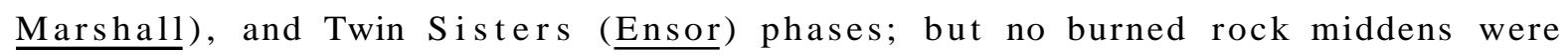
present (Young 1987).

Site 41BT6, a terrace site near a tributary of the Colorado River in Burnet County, was excavated by the SDHPT in 1981 (Young 1985b). This site produced a 
small amount of material from the Clear Fork Phase (Nolan dart points) and a great majority of artifacts representing the Twin Sisters Phase (Fairland, Ensor, Erio, and Darl). A Type 4 midden (a single layer of scattered rocks) was thought to be associated with the Twin Sisters Phase (Young 1985b).

In Llano County, a burned rock midden site (41LL78) on a terrace of the Llano River was excavated by the SDHPT (Patterson 1987). A few Late Paleo-Indian/ Early Archaic (San Geronimo) artifacts (Angostura and Gower) were recovered, but the majority of the material recovered represented the Round Rock (Marcos and Castroville) and the Twin Sisters (Ensor, Fairland, Darl, and Frio) phases. Circular concentrations of rock clusters indicated the remains of at least seven house structures, but temporal assignment of the structures was not possible because of the deflated nature of the site (Patterson 1986:113).

In Kerr County, the SDHPT excavated two burned rock midden sites (41KR107 and 41KR109) in the Guadalupe River drainage (Luke 1980). These sites produced Late Paleo-Indian/Early Archaic artifacts (Angostura) and artifacts characteristic of

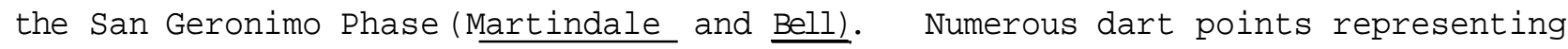
the Clear Fork Phase ("Early Triangular," Nolan, and Travis) also were recovered and were thought to be associated with the middens (Luke 1980).

Another burned rock midden site (Hop Hill) was excavated in Gillespie County by the University of Texas at San Antonio (UTSA) (Gunn and Mahula 1977). Virtually all Archaic phases were represented, but the phases which seemed to have been most prominent were the San Marcos and the Twin Sisters. The San Geronimo Phase was represented by the Martindale and Uvalde types; the Clear Fork Phase was represented by the Bulverde and Nolan types; the Round Rock Phase was represented by the Pedernales and Langtry types; the San Marcos Phase was represented 
by the Lange, Castroville, Marshall, and Montell types; and the Twin Sisters Phase was represented by Erio, Ensor, Wells, Darl, Yarbrough, and Fairland points. Based on an analysis of occupational floors, the authors hypothesized that the midden accrued basically during the Round Rock Phase and that subsequent occupations were coincidentally located atop the midden (Gunn and Mahula 1977:224) .

In 1986 Creel undertook a study to determine the functional relationship of burned rock middens to acorn processing (Creel 1986). Creel compared the distributions of live oak savanna and burned rock middens in west Central Texas and concluded that there was a meaningful correlation between them. He interpreted the data to indicate that acorns were being extensively used during the times that burned rock middens were formed. In addition, he determined that Weir's Type 1 and Type 2 middens had similar distributions and therefore were both probably related to the use of acorns (Creel 1986:153).

The Archaic Period terminated around A.D. 700 (Prewitt 1981a). Hallmarks of the succeeding period, the Late Prehistoric, are the use of the bow and arrow and pottery. It has been suggested (Prewitt 1981a) that the basic hunting and gathering subsistence strategies of the preceding Archaic Period continued much unchanged into the Late Prehistoric Period. The period has been divided into an earlier Austin Phase and a later Toyah Phase. The Austin Phase ended around A.D. 1200 (Prewitt 1981a) and is characterized by Scallorn, Edwards, and Granbury arrowpoints. The Toyah Phase is characterized by Perdiz and Cliffton arrowpoints and terminated with the inception of the Historic Period around A.D. 1750 (Prewitt 1981a). The Historic Period itself was marked by the beginning of European contact which ultimately brought about the demise of the native cultures in the Central Texas Archaeological Region. 
Late Prehistoric sites in the Central Texas Archaeological Region include the Smith Rockshelter in Travis County (Suhm 1957), the Kyle Site in Hill County (Jelks 1962), the Loeve-Fox Site in Williamson County (Prewitt 1981b), and the Rainey Site (Henderson ms.).

At the Smith Rockshelter a 9-in. sterile soil layer separated several feet of Austin Phase deposits from a single Toyah Phase deposit. Ceramics were present in the Toyah Phase component (Suhm 1957).

At the Kyle Site, Jelks was able to compile a list of culture traits unique to each Late Prehistoric phase as the result of unquestionable separation between the Austin and Toyah phases (Jelks 1962). He postulated that, in addition to $\underline{\text { Scallorn and Granbury }}$ arrowpoints, only the Austin Phase contained Friday knives and serrated flakes. Likewise, only the Toyah Phase contained Covington knives, double-pointed and four-edge beveled knives, small drills, snub-nosed end scrapers, bison bone, and pottery (Jelks 1962). Radiocarbon dates at the Kyle Site placed the Austin Phase between A.D. 411 and A.D. 951 and the Toyah Phase between A.D. 1131 and A.D. 1691 (Jelks 1962).

At Loeve-Fox, Prewitt was able to factor out additional traits unique to each Late Prehistoric phase (Prewitt 1981b). The Austin Phase produced large basinshaped hearths, burned clay/charcoal pits, and marine shell ornaments. The Toyah Phase produced plano-convex end scrapers, Leon Plain ceramics, and large flat hearths. Prewitt dated the Austin Phase at A.D. 700 to A.D. 1300 and the Toyah Phase at A.D. 1300 to A.D. 1750.

The Rainey Site produced a stratified sequence of transitional Late Prehistoric, Early Austin, Late Austin, Early Toyah, and Late Toyah occupations (Henderson 
ms.). Within this sequence, the Edwards type was found to underlie all other previously established types and the Sabinal type was placed firmly within the Late Austin Phase. A wide range of radiocarbon dates placed the transitional Late Prehistoric occupation between A.D. 580 and A.D. 810, the Early Austin Phase between A.D. 700 and A.D. 1180, and the Late Austin Phase between A.D. 940 and A.D. 1120 (Henderson ms.). Dating of the Toyah Phase zones remains problematical at this time.

A frequent occurrence in the Central Texas Archaeological Region is the presence of Austin and Toyah Phase materials atop burned rock middens of presumably earlier age. This phenomenon was noted at many of the Archaic sites discussed above. At Site 41KM61, a Toyah Phase occupation was present atop the midden occupations, and a Site 41KM62, Leon Plain ceramics and unclassified arrowpoints were also present (Young 1986).

At Site 41BT6, Austin Phase materials (Scallorn) and Toyah Phase materials (Perdiz) were recovered in association with a Type 4 midden (Young 1985b). At Site 41LL78, the Austin and Toyah phases were represented by Scallorn, Alba, $\underline{\text { Cliffton, }}$ and Perdiz arrowpoints and Leon Plain pottery (Patterson 1986). At Hop Hill, Fresno, Cuney, Perdiz, Scallorn, Young, and Edwards arrowpoints were recovered (Gunn and Mahula 1977).

At least one site is known where arrowpoints have been recovered from deep within the structure of a midden and are presumed to have been directly associated with the accretion of the midden. This site is 41 UV86 and was excavated by the SDHPT in 1982 (Goode ms.). Preliminary conclusions are that the midden was formed during the Late Prehistoric Period. 


\section{SITE DESCRIPTION}

Site 41MS32 is located on the north bank of Honey Creek adjacent to FM 1871 and an older county road which removed part of the site. About 500 meters downstream, Honey Creek meets Turtle Creek and from this point flows southward approximately $3.1 \mathrm{~km}$ (2 miles) to its confluence with the Llano River.

The landform upon which the site occurs is a Holocene terrace deposit overlying a bench formation of much greater age. With a maximum elevation of $1420 \mathrm{ft}$. at the west right-of-way, the ground surface across the site follows a gentle slope to the south, toward the creeks. Northward, across FM 1871, the surface rises more sharply to hilltops (Gorman and Tanyard Formations) in excess of $1700 \mathrm{ft}$. elevation.

Currently, approximately one-half of 41 MS32 is in cultivation with Klein grass, a dense cover which, prior to cutting, effectively obscured the sparse cultural material. The site area adjacent to Honey Creek is in a natural state or pasture and cultural materials are much more visible.

The most prominent cultural feature is a thin burned rock midden of moderate proportions, located on the highest portion of the site adjacent to the old abandoned county road. The road cut of this roadway removed the western section, perhaps one-fifth, of the burned rock midden. This roadway roughly parallels FM 871.

Prior to clearing, only the southern and eastern sections of the burned rock midden were readily visible; the remainder was obscured by four large live oak trees and other vegetation. 
Also obscuring and disturbing the burned rock midden were barbed wire fences, a goat shed, and to a lesser degree, the various activities of livestock. In addition to the extensive damage to the burned rock midden by tree roots, several sizable animal burrows hint that overall disturbance through time by natural agents has been considerable.

Due to these various forms of modification, the original form of the burned rock midden is difficult to assess. Its general appearance is that of a low, circular mound approximately 20 meters in diameter. However, a slight depression somewhat east and south of the apparent midden center is suggestive of a possible oven/hearth area. If this proves to be the case, one of three existing classification schemes (Weir 1976; Prewitt 1976; Creel 1986) could be chosen to describe the midden.

North and east of the burned rock midden, further disturbance of the site has resulted from land clearing and cultivation procedures. At least $10 \mathrm{to} 20 \mathrm{~cm}$ of the topsoil has been redistributed or removed from the cultivated area of the site. Evidence of this is represented by the soil islands on which the surviving trees still stand. 


\section{GEOLOGY/SOILS}

Situated within and near the southwestern terminus of the Llano Uplift geological region of central Texas, Site 41MS32 is surrounded by formations of Paleozoic age. Formations of the immediate vicinity are the Marble Falls Limestone and the Smithwick Formation which is composed of claystone, siltstone, sandstone, and conglomerate. These formations are of Pennsylvanian age. Other major formations north and west of the site are the Gorman and Tanyard Formations of the Ellenburger Group. Composed primarily of limestone and dolomite, these formations provided much of the chert used by the local prehistoric population.

Upstream of Site $41 \mathrm{MS} 32$ and west of the city of Mason, Honey Creek cuts through older formations such as the Hickory Sandstone and Town Mountain Granite, and the younger Edwards Limestone of Cretaceous age. All of these formations could have produced raw material which was used at $41 \mathrm{MS} 32$.

Soils of both alluvial and colluvial origin produced the relatively shallow soil profile which contains cultural material at 41MS32. A typical profile consists of a dark-brown loam topsoil, underlain by a reddish brown clay-loam which contains moderate amounts of mostly pebble-size gravel. At a depth of 60 to $70 \mathrm{~cm}$ the matrix is a pale-brown clay-laom with abundant gravel, mostly small to medium pebble size but ranging up to medium cobble size. Cultural material plays out at this depth.

Bedrock occurs at varying depths across the site and ranges from hard to soft limestone to a weathered, calcareous matrix. 
The site was cleared of vegetation, fences, and the shed, and a partial grid was established using a transit and a 30-meter tape. The centerline of the new right-of-way was chosen as the primary north-south grid line, oriented around station 380+00. This marker was designated N15/W0 on the grid. The first test units, Test Unit 1 and Test Unit 2, were placed on this line, at N5/W0 and N42/E1.

Prior to excavation, elevations of unit corners were recorded with the transit. Excavation then proceeded with the corners of each level measured directly from the ground surface.

The brief test excavation of site 41MS32 was aimed at determining site extent and depth of deposit, as well as some indication of its age and cultural affiliation. Of these goals the first two were adequately determined, but the latter was only partially successful. For this abbreviated testing phase, only minimal information was expected.

Excavation was conducted both by hand-dug units and Gradall trenching. From cultural materials on the surface and Gradall trenches the potentially most productive areas were located and tested by hand-dug units. A total of four units was excavated: three of 1- by 2-meter size and a 1- by 1-meter unit (Fig. 2). Two of the 1- by 2-meter units and the 1- by 1-meter unt were excavated to sterile soil at a depth of approximately $70 \mathrm{~cm}$. Time constraints did not allow the other unit to be excavated below $40 \mathrm{~cm}$. 


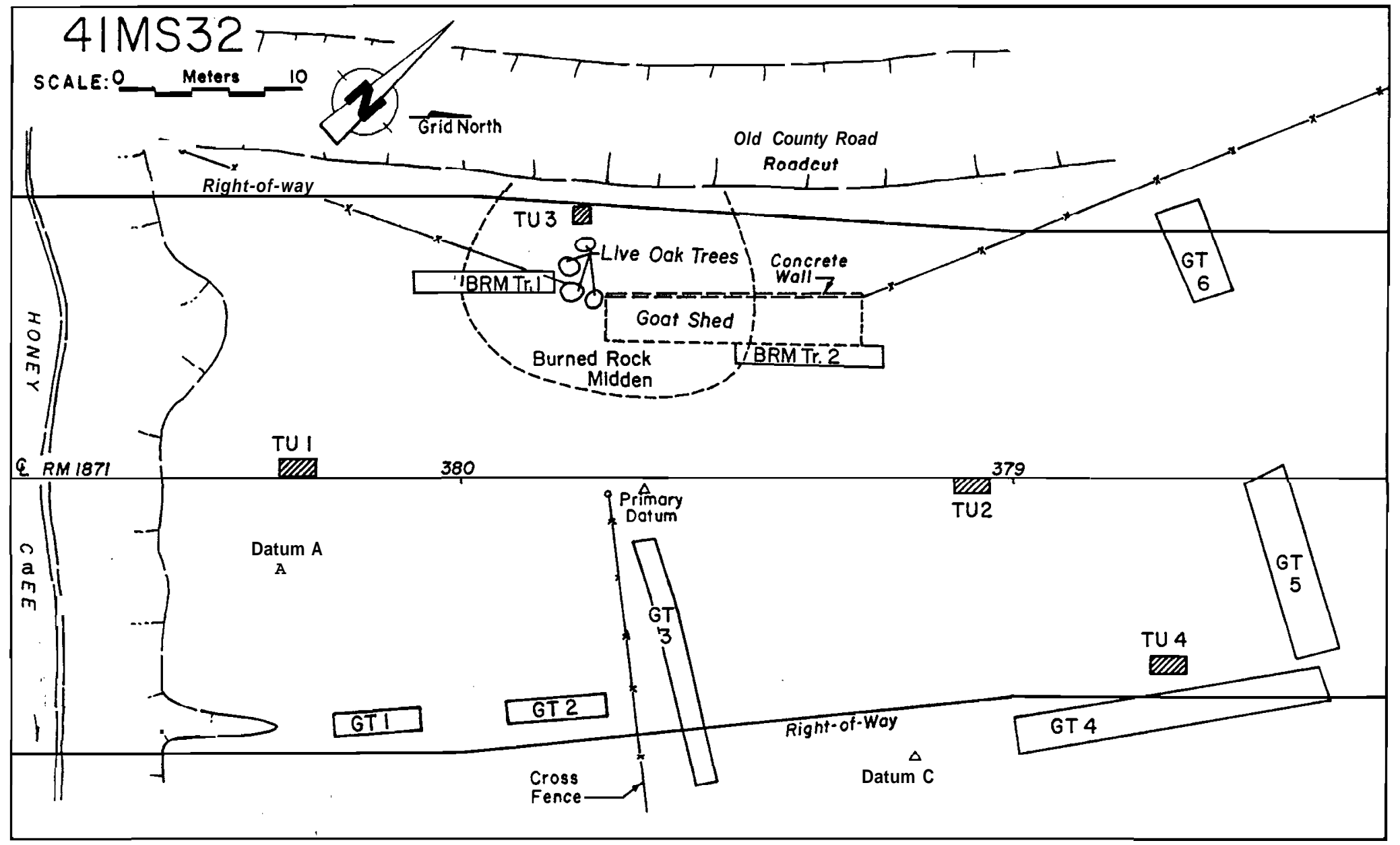

Figure 2. Plan view of site showing test units and Gradall trenches. 
Excavation was performed with the usual complement of large and small tools: shovel, mattock, geologist's hammer, trowel, brush. Geologist's hammers and mattocks were the primary tools used in the burned rock midden in Test Unit 3.

The matrix was screened through 1/4-in. hardware cloth, with the recovered artifacts placed in appropriately labeled bags. Also collected from the screen were the fire-cracked rocks which occurred in widely varying amounts. These were placed in a separate 816 paper bag and the number of bags (volume/weight) per level was recorded. The fire-cracked rock from Test Unit 3, within the burned rock midden, was so abundant that it was collected and measured in 3-gallon buckets. The number of buckets per level was recorded in the level notes.

As usual, the Gradall was invaluable in determining site size and depth. A total of 18 Gradall trenches was dug, 15 north of Honey Creek in and beyond the 41MS32 area and three south of the creek, in a nonsite area. The 5-ft. Gradall bucket was used for the most part, but a $3-\mathrm{ft}$. bucket was used in Burned Rock Midden Trenches 1 and 2 and in Gradall Trenches 1, 2, and 3.

The matrix removed from Burned Rock Midden Trench 1 was not screened but was spread on the ground surface away from the midden and further spread with a shovel. A total of 2 manos and 4 flakes was found in this heavily root-infested matrix. This technique would certainly miss many small artifacts but was done with sufficient care to find a representative sample, perhaps a majority of the material. This trench had an extremely low artifact density.

A sizeable portion of the matrix from Burned Rock Midden Trench 2 was screened, producing a substantially larger artifact sample than did Burned Rock Midden Trench 1. The most likely reason for these disparate results is not that the 
Burned Rock Midden Trench 2 soil was screened, but that this trench removed only a very small portion of the burned rock midden whereas Burned Rock Midden Trench 1 was almost entirely within the midden. Therefore, the majority of these artifacts came from outside the burned rock midden proper, perhaps in an area of relatively increased artifact density.

At any rate, Burned Rock Midden Trench 2 revealed that the northern sector of the midden is relatively shallow and does not extend as far northward as was first anticipated. More importantly, it revealed a possible burned rock hearth feature and an area of relatively high artifact density. 
BURNED ROCK MIDDEN OVERVIEW

Of the several prehistoric features recorded during the testing phase, the most important and complex is the burned rock midden. Varying considerably in age, size, use-formation, and complexity, these mounds of thermally fractured rock remain enigmatic after 60 years of investigation.

However, in the last two decades considerable progress has been made toward understanding these sometimes imposing mounds of detritis (Hester 1971; Weir 1976; Prewitt 1982a; Peter 1982; Black and McGraw 1985; Creel 1986). Of particular interest is the thesis that Central Texas burned rock middens were somehow associated with processing the fall mast crop (Hester 1971; Weir 1976).

This idea has been taken beyond speculation to a well-documented positive correlation between live oak savanna and burned rock midden locations in west Central Texas (Creel 1986).

Within Central Texas, particularly the western half, there is a strong possibility that parts of some burned rock middens were involved in or accumulated from the processing of other plant foods such as sotol (Prewitt 1981a). In particular, Late Prehistoric burned rock middens of this region might be functionally similar to the ubiquitous West Texas middens of the same era. Middens of Late Prehistoric age were recorded in Uvalde County as early as the 1930 s (Huskey 1935). One of these late middens was excavated by the SDHPT in $1982-83$ in northern Uvalde County (Goode ms.). This small midden had a central oven area much like those found in the West Texas middens.

In general appearance the $41 \mathrm{MS} 32$ midden is somewhat remindful of Late Prehistoric middens. It is relatively small, with a slight depression which is 
a possible oven area, has very dark ashy soil, and may contain charcoal; one arrowpoint was found nearby. In two of the three tested areas very few lithic artifacts were found, but this is probably not a temporally meaningful statistic. The manos found both in and outside the midden, however, may have been associated with the foods processed in or near the midden, and could have significant temporal implications.

Mason County lies along the southeast fringe of Creel's west Central Texas study area near the heart of Central Texas, in a region which has seen little archaeological investigation. Thus, Site 41MS32, which lies intermediate of the regions to the west, south, and east which have experienced considerable investigation of burned rock middens, could be an important link in understanding burned rock midden use across Central Texas. 


\section{ARTIFACTS}

A range of lithic debitage/tools typical of habitation/procurement sites is present here. This includes cores, cortex and interior flakes, biface failures, and rejuvenated tools. A relatively small sample of diagnostic artifacts/tools was recovered in the testing of 41MS32. Among these are 3 dart points, 3 arrowpoints, 1 drill, 1 scraper, and 1 biface preform which are illustrated in Figure 3.

The lithic debitage has not been analyzed, but a sufficient amount has been observed to see general patterns. With at least minor outcrops occurring nearby, a large majority of the lithic sample is of local origin. Whether considered a local source or not, the Llano River is only 2 miles away, and, undoubtedly, was a major flint source through time.

Specimen A

This specimen belongs to the Bell-Andice series which dates toward the end of the Early Archaic (Weir's San Geronimo Phase) (Weir 1976). It is made of a light-brown mottled flint, has light patination, and was broken by impact fracture. Length is $53 \mathrm{~mm}$; width is undetermined; and thickness is $6 \mathrm{~mm}$. Test Unit 2, Level 5, produced this specimen.

\section{Specimen B}

Identified as an "Early Triangular," this piece is roughly the same age as the Bell-Andice specimen. A heavy patina obscures the natural color; it was broken by transverse fracture. Length is $49 \mathrm{~mm}$; width is $37 \mathrm{~mm}$; and thickness is $5.5 \mathrm{~mm}$. Its location was Level 6 of Test Unit 2 . 


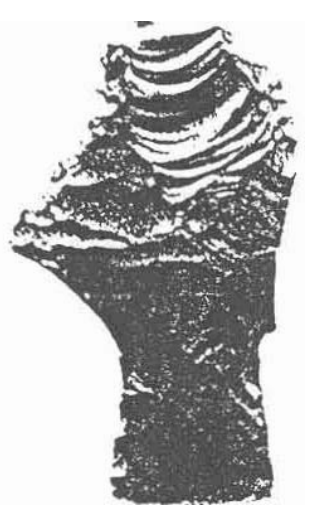

A

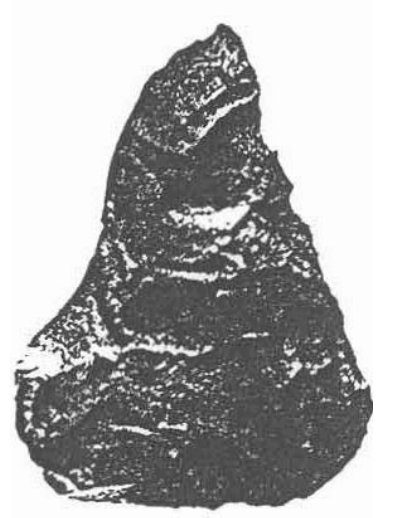

B
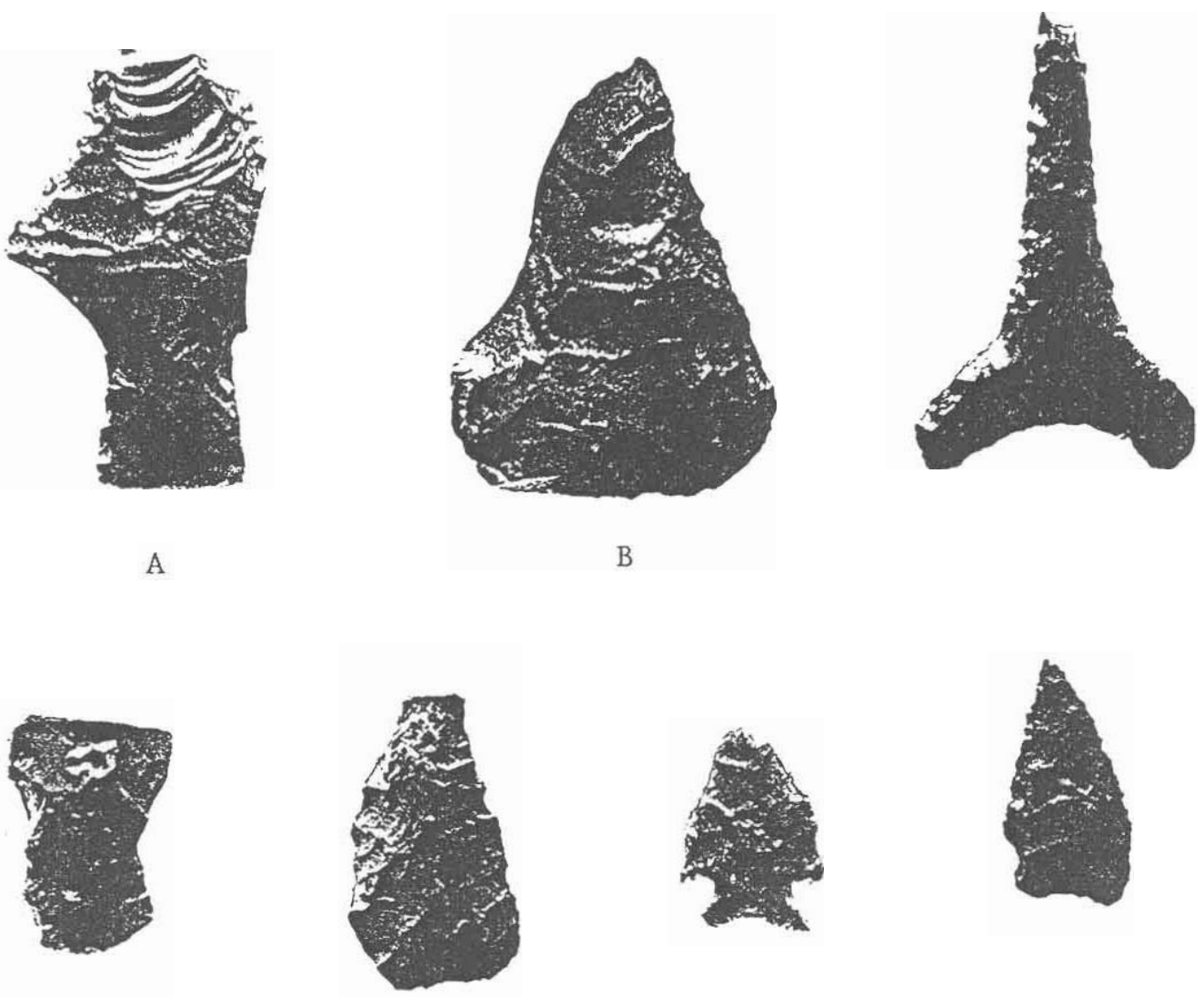

D

E
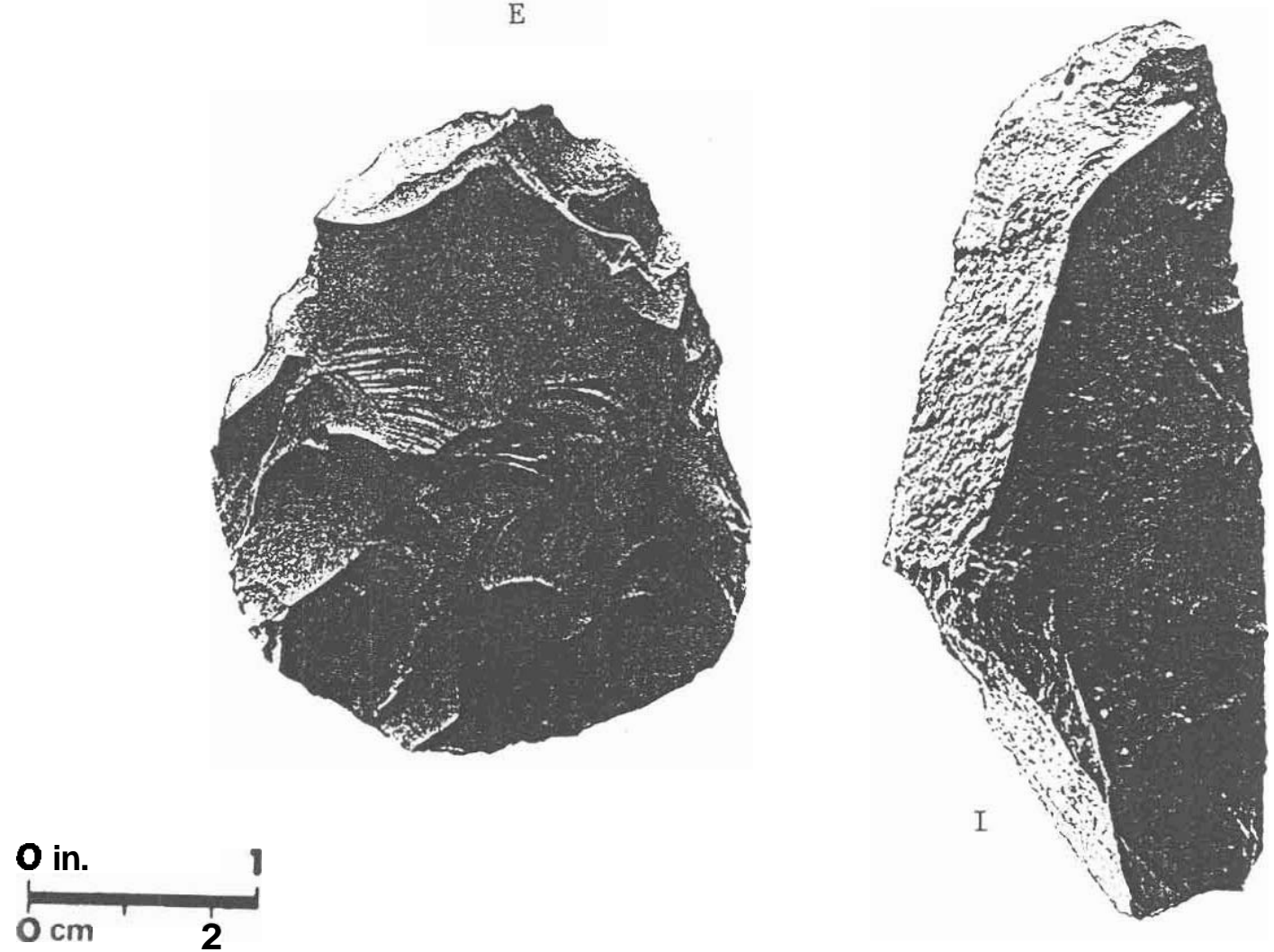

FIGURE 3. Artifacts. A, Bell-Andice; B, "Early Triangular;" C, drill; D, Middle Archaic/ Travis; E, possible arrowpoint; F, Edwards; G, arrowpoint; H, biface preform; I, side scraper. 
Specimen C

Although well made, this drill is nondiagnostic. It was found in Test Unit 1, Level 5, the same level as Specimen D which is apparently of early Middle Archaic age. Specimen $C$ has light patina on one face. Length is $51 \mathrm{~mm}$; width is $31 \mathrm{~mm}$; and thickness is $5 \mathrm{~mm}$.

Specimen D

Broken in use, discolored and further damaged by fire, this piece has nevertheless been labeled as Middle Archaic, perhaps of Travis age (Weir's Clear Fork Phase) (Weir 1976). Both Specimens C and D were found in the same level as Feature 1, which consists of two concentrations and a scatter of burned rock. Original length and width of this specimen are unknown; thickness is $7 \mathrm{~mm}$.

Specimen $E$

Made of dark-gray flint with blue mottles, this piece has been either considerably rejuvenated or is an arrowpoint failure. It is rather thick to have been a completed arrowpoint. This good quality material is of local origin. It was found in Test Unit 2, Level 1. Length is $33 \mathrm{~mm}$; width is $20 \mathrm{~mm}$; and thickness is $5.5 \mathrm{~mm}$.

Specimen $\mathrm{F}$

This Edwards point has been reduced in size through use-rejuvenation. Only small flakes were removed on the ventral face, leaving much of the original scars intact. It is made of light-brown and light-yellow flint, and also was 
found in Test Unit 2, Level 1. Length is $24 \mathrm{~mm}$; width is $18 \mathrm{~mm}$; and thickness i s $3.5 \mathrm{~mm}$.

\section{Specimen G}

The shape of this specimen was much altered by use and rejuvenation. It has faint side notches and a concave base, traits of the Austin Phase Scallorn and

Edwards types. It is made of dark-gray local flint. Length is $28 \mathrm{~mm}$; width is $15 \mathrm{~mm}$; and thickness is $3.5 \mathrm{~mm}$.

\section{Specimen $\mathrm{H}$}

This unfinished biface is made of superb blue-gray flint; it is heavily patinated on one face, lightly so on the other. It was found in the back-dirt of Gradall Trench 5. Length is $74 \mathrm{~mm}$; width is $62 \mathrm{~mm}$; and thickness is $11 \mathrm{~mm}$.

\section{Specimen I}

Found in the backdirt of Gradall Trench 2, Specimen $I$ is a side scraper made on a flake-blade. The entire right edge was carefully shaped and trimmed. It is made of gray chert, the poorest of three grades of locally occurring gray chert/flint. Length is $99 \mathrm{~mm}$; width is $43 \mathrm{~mm}$; and thickness is $14 \mathrm{~mm}$. 
MITIGATION PLAN FOR SITE 41MS32

General Excavation Procedures

The mitigation of Site 41MS32 represents only the third archaeological investigation, and the first professional excavation of a prehistoric site, in Mason County.

With necessary modifications for special situations, the general excavation and recording techniques applied in the testing phase also will be used during mitigation. The excavation of Site 41MS32 will commence in the area near Honey Creek. Here, a few meters southwest of Test Unit 1, an apparent hearth has been exposed by erosion. Its extent is unknown but it appears to be related to a later time period than Feature 1 in Test Unit 1. Excavation of this feature/area will be sufficient to determine if related features are present, perhaps resulting in a block excavation of three contiguous 2- by 2-meter units. From here, work will progress upslope, starting in the area between Station 380 and Gradall Trenches 1 and 2 (Fig. 2). Neither trench was particularly productive, perhaps indicating that this will not be a high priority area. Random placement of three $1-$ by 1 - and 1 - by 2 -meter units should be sufficient to assess this area.

In the northern portion of the site, Gradall Trenches 4 and 5 were rather productive; much less material was seen in Gradall Trench 6. A section of a hearth remains intact in Gradall Trench 5 and at least one other was removed. No diagnostic artifacts were found in this operation; however, a mano and a biface came from Gradall Trench 5.

Judging by the diagnostic artifacts found in Test Unit 2, there are at least two time periods represented in this area; the Early Archaic and the Late 
Prehistoric. It would be unusual if only these periods were present; therefore, evidence of other Archaic episodes is expected.

Further investigation here initially will employ excavation units of varying size to locate concentrations of cultural material. Additional use of the Gradall may be employed to isolate features by shallow scraping of the upper $10 \mathrm{~cm}$ of the grass-covered topsoil. If concentrations can be isolated, several small block excavations (2- by 2-meter units) will be used to investigate them.

With the potential of this rather large area still unknown, it is difficult to set a precise excavation figure. Considering its size and the potential return indicated by testing, it would be difficult to adequately sample this area with fewer than twenty-five $1-$ by 1 -meter units.

Mitigation of the burned rock midden, the primary feature at Site 41MS32, will concentrate on extracting a significant body of information from a low to moderate amount of excavation. Toward this end an excavation plan has been formulated, designed to answer several questions, regarding the totality of the burned rock midden phenomenon at this site.

Several research objectives need to be addressed in the excavation of the burned rock midden. These are:

1. Determine the type of burned rock midden. At this time, classification of the burned rock midden is uncertain. It could be similar to Weir's Type 1 or Type 2 (Weir 1976), Creel's Category 1 or Category 2 (Creel 1986), or some variation of these.

2. Determine the midden's age. Its relatively small size may indicate a rather restricted time of use. 
3. Locate and define internal features. These could be invaluable in dating the midden and in meeting the fourth objective.

4. Determine how the midden was used, what materials were processed, and if use was related to formation.

5. Define artifact categories and distribution.

6. Collect constant volume samples in $20 \mathrm{~cm}$ columns. These will be used for soil humate dating, soil chemistry studies, flotation, and fine screening to identify the kinds of foods which may have been processed in the midden.

7. Establish volumetrics of the burned rock midden as applied at $41 \mathrm{BX} 228$ (Black and McGraw 1985) which include volume of the burned rock midden, total rock weight, rock density per level, and so forth. Burned rocks will be collected in 3-gal. buckets and recorded per level. Information on rock size and number will be recorded for selected units or levels.

Excavation procedure for the burned rock midden consists of four strategies, considered to be of equal importance.

Strategy 1 entails establishing three machine-cut profile trenches which intersect at right angles, forming a "T" shape. The initial profile trench will be oriented eastwest and can span the entire midden, concrete wall notwithstanding. The secondary trenches will bisect the northern and southern halves of the midden .

Strategy 2 will be to determine if an oven area, located centrally or possibly in the southeast quad, is present. The first exploration for this feature will 
involve the east-west profile trench. Hand-excavated expansion from the trench may be required to complete exploration.

Strategy 3 will entail a sample excavation of each quadrant. The units will be hand excavated and the purpose will be to determine artifact and burned rock distribution and density as well as to locate possible intact features. With less root disturbance, the northern half of the midden may be more conducive to intact feature location.

Strategy 4 will be to examine the burned rock midden perimeter for features and artifact concentrations. Excavation should continue off-midden for the same kinds of information recovered from other excavations at the site. A possible feature was exposed at the midden edge by Burned Rock Midden Trench 2 and an arrowpoint came from the north end of the trench. Lithic debitage seems to be more abundant here as well. Strategy 4 may prove the most informative of all.

\section{Research Objectives}

Implementation of the excavation plan for Site 41 MS32 will be guided by several research objectives. These objectives, suggested by the findings of the test excavation, are thought to be the most pertinent and attainable for-this project. Most likely, all of these will not be met in full, and only very scant information may be forthcoming for some. Even so, it would be difficult to prioritize these objectives, each one being essential to a thorough understanding of the cultural systems which operated here. 
OBJECTIVE 1

Objective 1 is to establish cultural chronology/affiliation from a sequence of diagnostic artifacts/datable material. Generally, the cultural chronology of the 41 MS32 vicinity should reflect the pattern found across much of the Central Texas Archaeological Region. This area is of such great size, however, that several more or less distinct regions can be recognized. Some part of the central mineral region, including Mason County and at least parts of the surrounding counties, may comprise such a region.

From the few private collections seen to date, certain diagnostic artifacts and their frequency are somewhat different from regions to the east and south. For example, certain widespread trends in diagnostic artifacts, such as the notable diversity of the Early or Late Archaic eras, occur here but are represented in part by styles which are somewhat at variance with those of neighboring regions.

\section{OBJECTIVE 2}

Objective 2 is to identify certain elements of the subsistence base. The burned rock midden at Site $41 \mathrm{MS} 32$ could be the quintessential example of Creel's hypothesis of burned rock midden to live oak association. There are four large live oaks growing near the midden's center.

From Creel's work and the association of burned rock middens to acorns in widely separated regions such as North Fork Reservoir (Peter 1982) and Bandera County (T. R. Hester, personal communication, 1987), the importance of acorns in the Central Texas economy should no longer be in question. Even if similar evidence of acorn use is not found in this burned rock midden, its probable importance as 
a dietary supplement must still be inferred. With the live oaks growing in the midden, phytolith studies for oak would not be meaningful, but they can be directed toward identifying other species such as sotol. The presence of several manos across the site indicate vegetal processing.

In the testing phase a few mussel shell fragments were the only observed evidence of possible food sources. The fact that no bone was found probably reflects both the limited testing and an environment unsuitable to preservation. If the burned rock midden is relatively late, better bone preservation could be expected.

Other than oak, useful plants currently in the immediate vicinity include sotol, agarita, prickly pear, Texas persimmon, and mountain laurel.

OBJECTIVE 3

Objective 3 is to identify site activities and technology. The burned rock midden presents special problems which are discussed in detail elsewhere. At present, Site 41MS32 appears to be a short-term habitation locus whose prime attraction was a variety of subsistence resources in and along Honey Creek. The burned rock midden suggests intensive/repeated processing of certain resources, perhaps staples of the diet. That these were plant foods is also inferred from the presence of grinding stones.

The usual component of projectile points suggests that hunting was a major activity in the immediate vicinity. From the Late Prehistoric, the Perdiz points (found by local collectors) may have been intended for bison hunting. Planted in Klein grass today, the valley may look much as it did in Late Prehistoric 
times. As such, it would have provided adequate forage for a small herd of bison.

Manufacture and refurbishing of stone tools occurred at the site. To what extent is not known, but from the relatively small debitage samples, it appears that these activities were confined to specific/immediate need. This is not a quarry site, but appears to have been a minor procurement area.

\section{OBJECTIVE 4}

Objective 4 is to identify locally available resources and possible sources of nonlocal resources. Apparently, both food and material resources occurred in sufficient quantity to make this an attractive habitation site. Major plant resources probably included live oak acorns, sotol, prickly pear, agarita, and Texas persimmon. Mussel and other aquatic species may have been important dietary supplements. A variety of game should have been sufficiently abundant to play a major dietary role.

At least two varieties of chert, differing in texture and color, occur in the limestone hills north of the site and are widely scattered across the slope and terrace down to the creek.

At least one flake of quartz was found during test excavations. The nearest source of this material may be several miles upstream near the outcrops of granite.

The rock used in hearth construction and that which comprises the burned rock midden is mostly limestone; some coarse-grained sandstone also is present. These materials are locally abundant, occurring in the creek and on the surface 
upslope of the site. Some of the harder sandstone used as manos and granite cobbles may have washed downstream from outcrops several miles distant.

$$
\text { Logistics }
$$

It is anticipated that it will take a crew of six workers supervised by a professional member of the SDHPT cultural resources staff and a trained assistant approximately two months to accomplish the above-described research endeavors. 


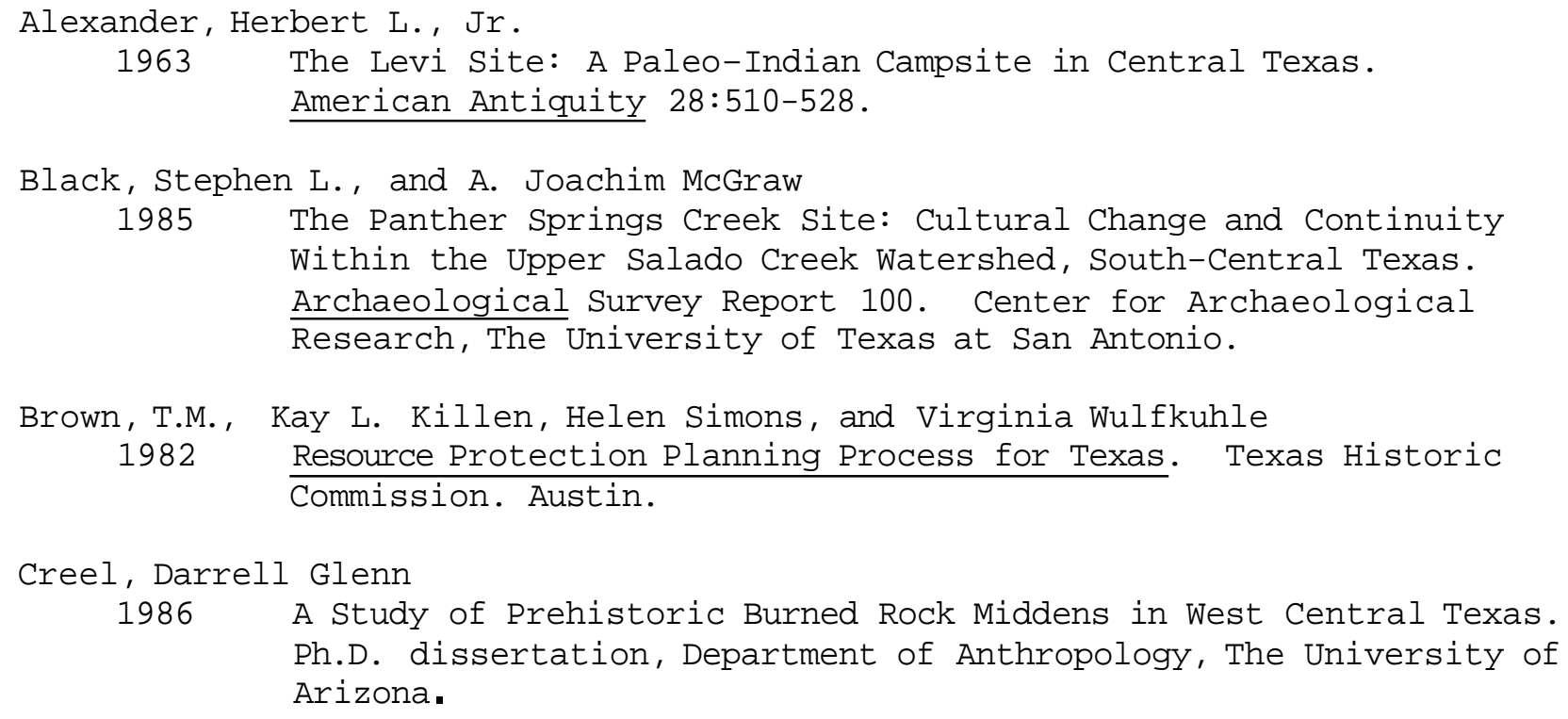

n.d. The Heard Site, 41UV88, an Archaic Burned Rock Midden Site in Uvalde County, Texas. Report in preparation for the Texas State Department of Highways and Public Transportation, Highway Design Division, Austin.

Hester, Thomas Roy

1971 Archeological Investigations at the La Jita Site, Uvalde County, Texas. Bulletin of the Texas Archeological Society 42:51-148.

1987 Personal communication with Glenn T. Goode regarding Site 41BN63. 


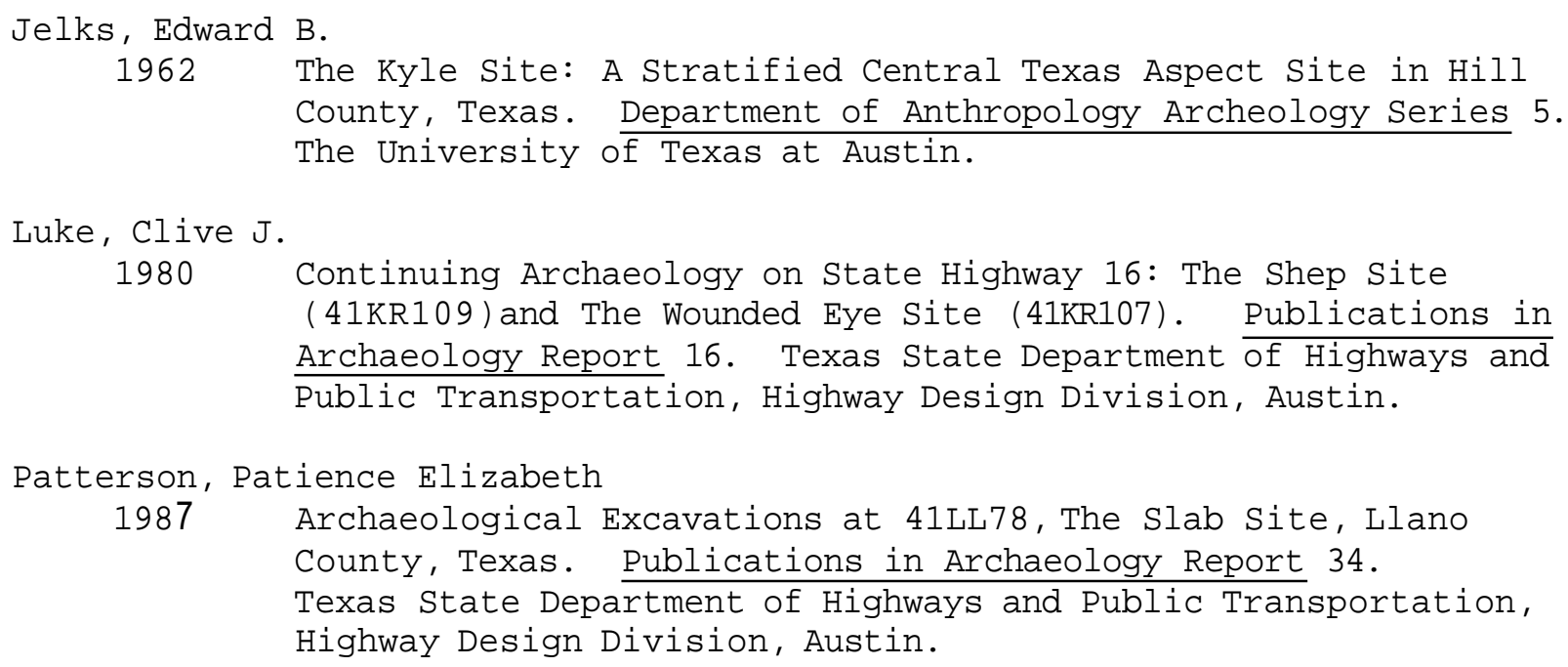

1981b Archeological Investigations at Loeve-Fox, Loeve and Tombstone Bluff Sites in the Granger Lake District of Central Texas. A ms. submitted to the Institute of Applied Sciences, North Texas State University, Denton.

Shafer, Harry J.

1971 Late Prehistory of Central Texas, 500 B.C. - 1700 A.D. Paper presented at the 74th Annual Meeting of the Texas Academy of Science, Nacogdoches, Texas.

Suhm, Dee Ann

1957 Excavations at the Smith Rockshelter, Travis County, Texas. Texas Journal of Science 9(1):26-58.

Weir, Frank A.

1976 The Central Texas Archaic. Ph.D. dissertation, Department of Anthropology, Washington State University, Pullman.

Young, Wayne C.

1985a A Preliminary Report on the Wilson-Leonard Site, 41WM235, A Major Paleo-Indian and Early Archaic Site in Central Texas. Ms. on file in the offices of the Texas state Department of Highways and Public Transportation, Highway Design Division, Austin.

1985b Archaeological Excavations at Site 41BT6: Burnet County, Texas. Publications in Archaeology Report 28. Texas State Department 


\author{
Young, Wayne C. (continued) \\ of Highways and Public Transportation, Highway Design Division, \\ Austin. \\ 1986 Archaeological Investigations in Eastern Kimble County, Texas. \\ Publications in Archaeology Report 30. Texas State Department of \\ Highways and Public Transportation, Highway Design Division, \\ Austin. \\ 1987 Archaeological Investigations at The Ammans Crossing Site, \\ 41KE93, Kendal County, Texas. Publications in Archaeology \\ Report 36. Texas State Department of Highways and Public \\ Transportation, Highway Design Division, Austin.
}

